\title{
Consanguine Philosophies of Traditional Timber-Based and Contemporary Sustainability-Based Forest Resource Management Plans
}

\author{
Thomas J. Straka*, Robert D. Tew, Tamara L. Cushing \\ School of Agricultural, Forest, and Environmental Sciences, Clemson University, Clemson, USA. \\ Email: "tstraka@clemson.edu \\ Received July $9^{\text {th }}$, 2013; revised July $10^{\text {th }}, 2013$; accepted August $22^{\text {nd }}, 2013$ \\ Copyright (c) 2013 Thomas J. Straka et al. This is an open access article distributed under the Creative Commons Attribution License, \\ which permits unrestricted use, distribution, and reproduction in any medium, provided the original work is properly cited.
}

\begin{abstract}
The earliest American forest resource management plans date to the birth of the forestry profession around 1900. For the next half century, these management plans were essentially timber production management plans. Certainly, other forest values, especially watershed protection, were important parts of the planning. But not until the second half of the twentieth century did multiple-use and a wide array of forest values become normal components of a forest management plan. Within the last twenty-five years forest management plans have developed a forest stewardship or sustainable forest management foundation. That is, a forest resource management plan is now expected to consider an entire set of forest values, to have a long-term sustainability focus, and to meet a set of expected management and operational criteria. Often, the forest management plan is the basis of a forest certification scheme. The early forest management plans were primarily timber-based and thus had a commercial or financial focus. Today's forest management plans are based on multiple forest values and may or may not have a financial focus. We contrast the traditional timber management plan with today's sustainable forest management plan, realizing the basis of both plans is by definition the forest or the timber. Involving both timber harvesting activities and the operational foundation of the sustainable forest management plan is essentially a timber management plan. One cannot ignore the fact that all forest management plans accomplish silvicultural objectives via manipulation of timber density variables, like stocking and spacing. Management of a forest still involves timber harvests. Our discussion shows that the timber management plan is still very much alive and forms the basis of modern sustainable forest management plans.
\end{abstract}

Keywords: Forest Management Plan; Forest Management Planning; Forest Sustainability; Sustainable Forest Management

\section{Introduction}

In the first half of the last century, forested properties that were administered under a management plan usually emphasized timber production [1-3]. These management plans had a strong foundation in forest regulation and included a cutting budget and a harvest plan [4]. The earliest plans stressed fire prevention, sound harvesting practices, and maintenance of adequate growing stock [5-7]. While a written plan was not considered mandatory for a small forest tract, most of these plans were very formal, written, and contained details well beyond what might be in a modern plan [8].

Many of these traditional timber management plans

${ }^{*}$ Corresponding author. focused on old-growth forests that were being liquidated [9-11]. Forest management was a gradual process on these tracts [12-14]. Thus, the forest activities stressed in these early plans differed from those stressed today [15]. However, timber management is always part of a forest resource management plan [8]. In order to achieve forest management objectives (whether they be timber production, wildlife habitat improvement, recreational development, or aesthetics) it is the trees that are manipulated [16-18]. The components of the traditional timber management plan are still crucial elements of the modern forest resource management plan [18].

Many forest owners still develop management plans that emphasize timber production [19-21]. Forest Industry, timber investment management organizations, real 
estate investment trusts, and millions of small family forest owners look at their forests as investments and expect management that produces reasonable rates of return [22]. Many family forest owners emphasize timber production and pay consulting foresters significant fees to ensure profitable operations [23]. Certainly, the management plans on these timber production lands are similar to the early traditional timber management plans, but they also consider multiple resources and forest sustainability issues [24-26], especially those management plans prepared in the private sector and by consulting foresters [27-30].

Very roughly speaking, for the first half of the twentieth century the traditional timber-based forest management plan dominated, for the second half of that century forest management plans were in transition with multiple-use forestry gaining more and more importance, and for the last few decades the sustainable forest management or forest stewardship plan has dominated [31-33]. Both foresters and forests gradually moved towards the concepts of forest sustainability [34]. Sustained-yield always played a role in American forestry, so the transition was not abrupt and the changes in forest management planning did not cause major problems [35]. At least on private forest lands the problems were minor; national forests and other federal lands often did have major adjustments to fundamental management philosophy [36-38].

The United States Department of Agriculture (USDA) Forest Service introduced forest stewardship as the forest sustainability model for family forest lands [39]. Since federal cost-share funding was often tied to the program and its management plans, private forest owners adopted forest stewardship [40]. At the same time, state forestry commissions and divisions were expanding forest stewardship across the country (with federal funding as the incentive) [41]. Family forest owners were required to develop broad forest sustainability-type management plans to qualify for cost-share programs [42-44]. Most states had model forest stewardship management plans tied to federal standards [45].

Forest certification, based on a forest sustainability foundation, developed as a major factor impacting forest resource management planning over the last two decades of the twentieth century [46-48]. Major deforestation of tropical rainforests, resulting in a dangerous loss of biodiversity, was the initial concern, but that concern quickly developed into one that encompassed global forests [49]. In 1988 the International Tropical Timber Organization developed a labeling process to identify tropical wood products produced under the principles of sustainable forest management [50-52]. This is called eco-labeling and represents a claim attached to a product that in- dicates its environmental characteristics, such as being produced under sustainable forest management principles [53]. Consumers can then direct their purchasing power towards environmentally-friendly products and firms [54].

Europe and North America generally already had significant environmental regulations and protections for both private and public forestlands [55]. However, some environmental groups were dissatisfied with the effectiveness of environmental regulations and pressured for tougher forest certification programs [56]. Environmental groups, forest industry, trade organizations, and forest owners participated in a process that produced multiple forest certification schemes [57]. Examples are the Forest Stewardship Council, the American Tree Farm System, and the Sustainable Forestry Initiative. These certification programs have gained wide acceptance and are an example of consumer-driven quasi-regulation [58-60]. The power of these programs is derived from consumer pocketbooks, not government regulation. They are destined to be a major contributory factor in the continuing acceptance and demand for sustainable forest management.

The two types of forest resource management plans that we discuss are the traditional timber managementbased plan and the contemporary forest sustainability forest resource management plan based on forest stewardship or sustainable forest management (forest certification-based plans). We discuss how the foundations of both plan types are identical and that the main difference is the additional factors incorporated into the contemporary plan. The traditional timber management plan, with its multiple-use focus, is actually quite similar to the sustainable forest management plan.

\section{The Traditional Timber Management Plan}

Timber management plans usually have three major parts: the foundation material, the plan for future management, and appendix information. Both past and present forest condition information is included, as past conditions can have a huge impact on the future potential of the forest. A complete timber management plan and the components is fairly standardized by forester custom, with additional detail added as needed. Table 1 summarizes the normal components in a timber management plan $[2,8,61]$.

The foundation material is the basis of recommendations for the future stand. The foundation material is factual and the future stand recommendations involve silvicultural and forest management analysis (including forest regulation and valuation). This material lays the foundation for sustained-yield forest management and provides the direction for activities. Enough flexibility is neces- 
Table 1. Traditional timber management plan components.

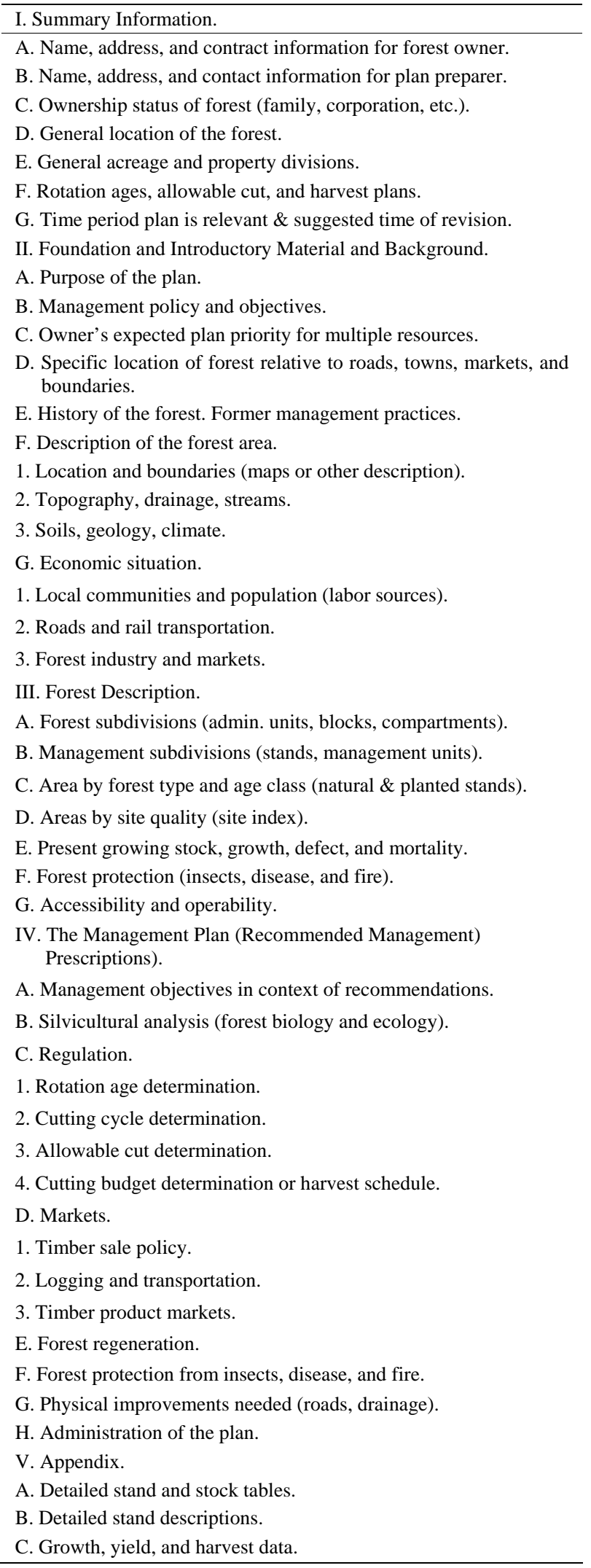

sary in the plan to handle unforeseen circumstances. Larger forests often include the detailed information listed in the appendix in Table 1.

The arrangement of a timber management plan is not fixed and Table 1 is just a suggested format. The type of ownership and the primary forest uses will determine the best plan format. A management plan is a report, and like all reports, should be formatted to its intended audience in terms of organization, writing, and depth. A long plan often has an executive summary of some sort, a table of contents, and perhaps a glossary. Of course it requires a title page with appropriate identifying information.

Table 1 is a fairly comprehensive list of timber management plan components. These plans obviously have a timber production-orientation and thus follow a forest regeneration-forest inventory-forest harvesting-timber sale and marketing-forest regulation format. It is possible to generalize and offer some broad categories of timber management plan components. Certainly not all plans will follow the exact format of Table 1. However, there are certain components that appear in virtually all these plans in one form or another.

The first item usually addressed is the landowner management objectives or the purposes of management. This is often not as easily obtained from the forest owner, who will often claim not to have specific objectives (or who will make some vague statement like "good forest management”). The plan will dictate levels of investment, intensity of management, kinds and amounts of forest outputs, and future forest conditions. From the smallest forest owner to the largest corporate owner or investor, these decisions cannot be left to one person's idea of what is "good". Since the management objectives determine the direction, magnitude, and expected outcomes of the plan, they must be established before any work begins on plan development.

The economic and resource environment surrounding the forest and forest owner will have large impacts on managerial possibilities and market opportunities. What resources (capital and labor) are available to manage the forest? What are the timber markets? How do the management objectives relate to markets? The larger the forest the more important forest organization and subdivisions become. How will the forest be organized? A small forest can easily be managed using stands and compartments. But larger forests can require significant organization.

Operability and accessibility issues can become large management issues. A timber management plan tends to be timber harvest-oriented. Transportation systems within the forest, harvesting terrain, and timber distribution by volume and type can dictate the levels of planning necessary. Typical timber management plans did concentrate on timber, but other forest values, like recreation, 
wildlife, and water resources were not ignored. They were often part of these plans, but timber was usually the priority.

Any forest resource management plan, or earlier timber management plan, always has a silvicultural basis. The important analysis that takes place as part of the planning process starts as a silvicultural analysis. All aspects of timber management have a foundation in silviculture. Detailed silvicultural analysis is not expected, but the silviculture factors that control the plan need to be identified and discussed. Forest protection from insects, disease, and fire is another fundamental forestry aspect that is expected to be addressed at an appropriate level.

As part of the planning process the forest is measured. An inventory is developed and growth and yield information calculated. An inventory of some sort is mandatory. However, this inventory (which can be costly to obtain) should be performed at a level commensurate with the planning needs. The forest inventory is sometimes confused with the planning itself. It is part of the planning process (the data collection part) and is a step in developing the management plan.

Forest regulation (a planning scheme to get the desired future forest condition and forest outputs) is always part of a timber management plan. Modern planning refers to this as harvest scheduling and the harvests can include non-timber goals. Traditional forest regulation is timberoriented and is concerned with timber outputs. Timber management plans contain the end result of forest regulation: a cutting budget. The cutting budget will directly determine the cash flows from the forest and forest owners concerned with investment return will have a high level of interest in this result. Forest regulation usually has a goal of sustained yield (of timber) and forest continuity. Just as forest continuity is crucial, so is planning continuity. Provisions should be made to update and revise the plan as needed and on a regular basis.

The traditional timber management plan still exists and is still functional for situations where the predominate forest output is timber. Most forest resource management plans today consider all resources in the forest (multipleuse) and stress forest sustainability. The one resource that is manipulated in forest resource management plans of all types is timber. Wildlife values, recreation values, water values, aesthetic values, all are manipulated by manipulating the timber resources. So timber management plans are foundations of most all forest management plans and the same framework used traditionally in timber management is found throughout forest resource management planning.

Detailed components of a timber management plan were presented. There is no one basic framework used by all forestry organizations. At the broadest level there is a general framework. A forest management plan should start out with the forest owner's management objectives, the forest should be described (usually stand-by-stand and with some level of forest inventory reported), recommendation for management should be made (usually overall and stand-by-stand, based on silvicultural analysis), a forest regulation framework is used to project forest outputs, and progress towards meeting objectives, especially future forest conditions, should be discussed.

Owners of small forests do not have high levels of forest outputs. Larger forests have detailed reports on forest outputs. Owners of small forests can have capital limitations that impede following plan recommendations. One schedule that is very popular with these landowners is a Schedule of Planned Activities over the planning horizon of the management plan. This should include expected costs or revenues associated with the activity. Costs in particular are much easier to cover when a plan warns the landowner on timing.

Consulting foresters, industry foresters, and foresters managing timber investments still follow the framework of the traditional timber management plan on much of the land they manage. Other lands might have plans that are multiple-use based, but timber management techniques will be a major part of those plans also. Forest resource management planning will continue to have timber management planning as its foundation.

\section{The Forest Stewardship/Sustainability Management Plan}

The contemporary forest stewardship/sustainable forest management plan does differ from the traditional timber management plan. However, the difference is in incremental or additional aspects covered and not in fundamental structure. Like the traditional management plan it follows a description-recommendation-protection format, but the emphasis will be on sustainability and stewardship, not timber. However, there is no reason a stewardship/sustainability-type plan cannot stress timber production.

Table 2 is an outline of a general forest stewardship/ sustainable forest management plan. This should not be thought of as a definitive outline, as there is considerable variation in how these plans are constructed. Clearly, it is very similar to the outline in Table 1. Both types of plans attempt to accomplish the same thing. At the same time, the two outlines are quite dissimilar. One is focused on a single resource and one is focused on multiple resources. One is focused on sustained yield and one is focused on sustainability. However, the two are much more similar than they are dissimilar.

In general, there are four additional components in the broader stewardship or sustainable forest management 
Table 2. Components of a stewardship/sustainability forest resource management plan.

I. Multiple-resource management objectives.

II. Stand descriptions and recommendations.

A. Tract history.

B. Past land use practices.

C. Wildlife habitat and conditions.

D. General timber conditions.

E. Stand-by-stand descriptions.

1. Timber conditions.

2. Wildlife and fish conditions.

3. Soils and water quality conditions.

4. Biodiversity and endangered species issues.

5. Recreation and aesthetics.

6. Forest health and invasive species.

7. Special sites.

F. Recommendations.

1. Management practices needed.

2. General timber harvest and other activities.

3. Wildlife/fish habitat improvements needed.

4. Soil and water protection.

5. Afforestation and reforestation plans.

III. Management of related resources.

A. Endangered species, biodiversity, invasive species.

B. Cultural resources and special sites.

IV. Wildlife food plots, if necessary.

V. Threatened and endangered species.

VI. Soil, water, and air issues.

A. Forest land erosion control issues.

B. Streamside and shoreline protection.

VII. General recommendations.

A. Best management practices.

B. Forest practices guidelines (sustainability).

C. Smoke management guidelines for prescribed burning.

VIII. Suggested management schedule.

A. Schedule of management activities.

B. Schedule of costs and revenues by year.

C. Schedule of timber and non-timber outputs.

IX. Maps and aerial photographs.

X. List of organizations providing natural resource advice.

XI. Glossary

plans. First, the management objectives will address multiple forest resources, not just timber resources. Granted, a timber management plan often addresses multiple resources, but the objectives are usually focused on the timber resource. The stewardship forest management plan always takes the broader focus.

Second, the stewardship/sustainability-type forest management plan will emphasize natural resources enhancement and protection. This means protection of special sites and a broader consideration of social factors, like adjacent owner concerns, recreation, and access. Soil, air, and water protection will be a major concern, including roads, streams, wetlands, ponds, lakeshore, effects of natural disasters, and even carbon sequestration. Fish, wildlife, and biodiversity must be protected. Wildlife is certainly a component of many timber management plans, but this level of broad protection would be unusual for such a plan. Endangered or threatened species protection is emphasized. Sustainability-type plans are subject to a wider range of forest management constraints.

Third, management of all forest resources, not just timber resources, is stressed. This goes beyond management objectives to a requirement that the interaction of resources be considered. For example, the relation of pastures and hayfields to wildlife habitat, maintenance of wildlife habitat and food plots for wildlife.

Fourth, there is an expectation of a broader set of general recommendations and guidelines in the stewardship/sustainability-type plan. Usually the plan covers aspects like best management practices, forest practice guidelines, and smoke management guidelines for prescribed burning.

There is a set of core sustainability concepts and principles that are evident in the stewardship/sustainability outline. Sustainability and stewardship management plans focus on active and adaptive management that meets the forest owner's management objectives and is consistent with the size of the forest and the scale and intensity of activities. There is an emphasis on complying with federal, state, and local laws in Table 2. Timely reforestation and afforestation that meets the owner's management objectives are in the sustainability outline. Table 2 strongly emphasizes protection of the environment (air, water, and soil) that considers state best management practices, integrated pest management, and that only uses prescribed fire in terms of management objectives. The second outline stresses protection of biodiversity (fish and wildlife). Outline 2 recognizes forest aesthetics, protection of special sites (historical, archeological, cultural, biological, and ecological). Finally, timber protection is a part of both outlines, but in the second outline it is not predominating and, like in the first outline, all timber harvests are conducted in accordance with management objectives and consider other forest values.

\section{Conclusions}

Timber management plans go back to the earliest Ameri- 
can forest management history. They are still commonly used today. However, most forestry organizations and owners use a more comprehensive forest management plan that more broadly considers environmental and sustainability issues. The two formats are compatible.

This should not be surprising as timber management planning dominated the early half of American forestry and a set of fundamental forest management planning principles developed [62]. These core principles became entrenched in forest management textbooks and literature [63-65]. The same set of principles is used to develop contemporary forest management plans [66]. For example, one key concept is that to be effective the plan must meet the landowner's objectives and it must developed at the proper scale (small forest tracts have different management problems that much larger forest tracts) [67-69]. That continues to be a key concept today.

American forest management planning requires, first, an understanding of timber management planning, an understanding of why timber management plans were constructed the way they were, and an understanding of the core principles of timber management planning. That same information is ingrained in the framework of contemporary forest management plans.

Forest sustainability changed the emphasis on forest management planning from timber and dollars to broader issues, but many forest owners consider their forests strictly as investments and utilize forest management plans that are primarily dollar-oriented.

Sustainable forest management requires a forest resource management plan that goes beyond the traditional timber management plan. There is no question about that. But contemporary plans must always contain the fundamentals of a timber management plan, as timber is the resource being manipulated to achieve goals. Foresters should not forget the connection between the two.

\section{REFERENCES}

[1] H. H. Chapman, “Forest Management,” J. B. Lyon Company, Albany, 1931.

[2] T. J. Straka, "Forest Resource Management Plans-A Landowner-Oriented Approach," Journal of Natural Resources and Life Sciences Education," Vol. 22, No. 2, 1993, pp. 111-115.

[3] H. A. Meyer, A. B. Recknagel, D. D. Stevenson and R. A. Bartoo, "Forest Management," 2nd Edition, The Ronald Press Company, New York, 1961.

[4] K. P. Davis, "Forest Management: Regulation and Valuation,” 2nd Edition, McGraw-Hill Book Company, New York, 1966.

[5] G. Pinchot, "Biltmore Forest, The Property of Mr. George W. Vanderbilt: An Account of Its Treatment, and the Results of the First Year's Work,” The Lakeside Press, Chi- cago, 1893.

[6] I. F. Eldredge, "Management Plans with Special Reference to the National Forests,” United States Department of Agriculture Miscellaneous Publication 11, Government Printing Office, Washington DC, 1928.

[7] B. T. Parry, H. J. Vaux and N. Dennis, "Changing Perceptions of Sustained-Yield Policy on the National Forests," Journal of Forestry, Vol. 81, No. 3, 1983, pp. 150-154.

[8] W. A. Leuschner, "Introduction to Forest Resource Management,” John Wiley \& Sons, New York, 1984.

[9] D. N. Bengston, T. J. Webb and D. P. Fan, "Shifting Forest Value Orientations in the United States, 1989-2001: A Computer Content Analysis,” Environmental Values, Vol. 13, No. 3, 2004, pp. 373-392. doi:10.3197/096327104323312734

[10] F. E. Olmsted, “A Working Plan for Forest Lands Near Pine Bluff, Arkansas,” United States Department of Agriculture Bureau of Forestry Bulletin Number 32, Government Printing Office, Washington DC, 1902.

[11] T. H. Sherrard, "A Working Plan for Forest Lands in Hampton and Beaufort Counties, South Carolina,” United States Department of Agriculture Bureau of Forestry Bulletin Number 43, Government Printing Office, Washington DC, 1903.

[12] L. S. Davis, K. N. Johnson, P. Bettinger and T. E. Howard, "Forest Management: To Sustain Ecological, Economic, and Social Values," 4th Edition, Waveland Press, Inc., Long Grove, 2001.

[13] P. Bettinger, K. Boston, J. P. Siry and D. L. Grebner, "Forest Management and Planning," Academic Press, Burlington, 2009.

[14] W. B. Kessler, H. Salwasser, C. W. Cartwright Jr. and J. A. Caplan, "New Perspectives for Sustainable Natural Resources Management,” Ecological Applications, Vol. 2, No. 3, 1992, pp. 221-225. doi:10.2307/1941856

[15] A. B. Recknagel, "The Theory and Practice of Working Plans (Forest Organization), John Wiley \& Sons, New York, 1913.

[16] J. Buongiorno and J. K. Gilless, "Decision Methods for Forest Resource Management,” Academic Press, Burlington, 2003.

[17] W. D. Klemperer, "Forest Resource Economics and Finance,” McGraw Hill, Inc., New York, 1996.

[18] W. A. Leuschner, "Forest Regulation, Harvest Scheduling, and Planning Techniques,” John Wiley \& Sons, Inc., New York, 1990

[19] W. A. Duerr, "Fundamentals of Forestry Economics," McGraw-Hill Book Company, New York, 1960.

[20] W. A. Duerr, "Introduction to Forest Resource Economics,” McGraw-Hill, Inc., New York, 1993.

[21] R. A. Sedjo, Ed., "Investments in Forestry: Resources, Land Use, and Public Policy,” Westview Press, Boulder, 1985.

[22] F. C. Zinkhan, W. R. Sizemore, G. H. Mason and T. J. Ebner, "Timberland Investments: A Portfolio Perspective,” Timber Press, Portland, 1992. 
[23] T. J. Straka and C. J. Childers, "Consulting Foresters' view of Professional Forestry Education," Journal of $\mathrm{Na}$ tural Resources and Life Sciences Education, Vol. 35, No. 1, 2006, pp. 48-52. doi:10.3390/su2020604

[24] T. J. Straka, "Evolution of Sustainability in American Forest Resource Management Planning in the Context of the American Forest Management Textbook," Sustainability, Vol. 1, No. 4, 2009, pp. 838-854.

[25] T. J. Straka and P. A. Layton, "Natural Resource Management: Life Cycle Assessment and Forest Certification and Sustainability Issues,” Sustainability, Vol. 2, No. 2, 2010, pp. 604-621.

[26] M. P. Washburn, S. B. Jones and L. A. Nielsen, "Nonindustrial Private Forest Landowners: Building the Business Case for Sustainable Forestry,” Island Press, Washington DC, 1999.

[27] V. A. Sample and S. Anderson, "Common Goals for Sustainable Forest Management: Divergence and Reconvergence of American and European Forestry," Forest History Society, Durham, 2008.

[28] V. A. Sample and R. A. Sedjo, "Sustainability in Forest Management: An Evolving Concept,” International Advances in Economic Research, Vol. 2, No. 2, 1996, pp. 165-173. doi:10.1007/BF02295056

[29] T. J. Straka, “Taxonomic Review of Classical and Current Literature on the Perennial American Family Forest Problem,” Forests, Vol. 2, No. 3, 2011, pp. 660-706. doi:10.3390/f2030660

[30] C. M. Watts, L. S. Pile, and T. J. Straka, "Sustainability and Forest Certification as a Framework for a Capstone Forest Resource Management Plans Course,” Open Journal of Forestry, Vol. 2, No. 3, 2012, pp.159-166.

[31] H. K. Steen, "History of Sustained Yield Forestry: A Symposium,” Forest History Society, Durham, 1984.

[32] J. L. Innes, G. M. Hickey and H. F. Hoen, "Forestry and Environmental Change: Socioeconomic Political Dimensions,” CABI Publishing, New York, 2005. doi:10.1079/9780851990026.0000

[33] C. Maser, "Sustainable Forestry: Philosophy, Science, and Economics,” St. Lucie Press, Delray Beach, 1994.

[34] D. W. Floyd, "Forest Sustainability: The History, The Challenge, the Promise,” The Forest History Society, Durham, 2002.

[35] D. W. Floyd, S. L. Vonhof and H. E. Seyfand, "Forest Sustainability: A Discussion Guide for Professional Resource Managers,” Journal of Forestry, Vol. 99, No. 2, 2001, pp. 8-28.

[36] D. B. Lindenmayer and J. F. Franklin, "Towards Forest Sustainability,” Island Press, Washington DC, 2003.

[37] B. Shindler and L. A. Cramer, "Shifting Public Values for Forest Management: Making Sense of Wicked Problems," Western Journal of Applied Forestry, Vol. 14, No. 1, 1999, pp. 28-34.

[38] C. D. Oliver, "Sustainable Forestry: What Is It? How Do We Achieve It?” Journal of Forestry, Vol. 101, No. 5, 2003, pp. 8-14.

[39] USDA Forest Service, "Forest Stewardship Program Na- tional Standards and Guidelines,” USDA Forest Service, State and Private Forestry, Cooperative Forestry, Washington DC, 2009.

[40] D. R. Russell Jr. and S. Stein, "Planning for Forest Stewardship: A Desk Guide,” USDA Forest Stewardship Program FS-733, 2002.

[41] Pinchot Institute for Conservation, "A Comparison of Guidelines for the Forest Stewardship Program and Other Standards of Sustainable Forest Management," Pinchot Institute for Conservation, Washington DC, 2008.

[42] F. M. Melfi, T. J. Straka, A. P. Marsinko and J. L. Baumann, "Landowner Attitudes toward South Carolina's Forest Stewardship Program,” Southern Journal of Applied Forestry, Vol. 21, No. 4, 1997, pp. 158-163.

[43] T. G. Thrift, T. J. Straka, A. P. Marsinko and J. L. Baumann, "Forest Resource Management Plans: Importance of Plan Components to Nonindustrial Private Forest Landowners in South Carolina,” Southern Journal of Applied Forestry, Vol. 21, No. 4, 1997, pp. 164-167.

[44] S. E. Daniels, M. A. Kilgore, M. G. Jacobson, J. L. Greene and T. J. Straka, "Examining the Compatibility between Forestry Incentive Programs in the US and the Practice of Sustainable Forest Management," Forests, Vol. 1, No. 1, 2010, pp. 49-64. doi:10.3390/f1010049

[45] M. A. Kilgore, J. L. Greene, M. G, Jacobson, T. J. Straka and S. E. Daniels, "The Influence of Financial Incentives in Promoting Sustainable Forestry on the Nation's Family Forests,” Journal of Forestry, Vol. 105, No. 4, 2007, pp. 184-191.

[46] B. Cashore, G. Auld and D. Newson, "Governing through Markets: Forest Certification and the Emergence of NonState Authority,” Yale University Press, New Haven, 2004.

[47] E. Hanson, R. Fletcher, B. Cashore and C. McDermott, "Forest Certification in North America," Oregon State University Extension Service, Corvallis, 2006.

[48] C. Maser and W. Smith, "Forest Certification in Sustainable Development: Healing the Landscape,” CRC Press, Boca Raton, 2001.

[49] E. Rametsteiner and M. Simula, "Forest CertificationAn Instrument to Promote Sustainable Forest Management," Journal of Environmental Management, Vol. 67, No. 1, 2003, pp. 87-98. doi:10.1016/S0301-4797(02)00191-3

[50] V. M. Vianna, J. Erwin, R. Z. Donovan, C. Elliott and H. Gholz, "Certification of Forest Products: Issues and Perspectives,” Island Press, Washington DC, 1996.

[51] K. Vogt, B. C. Larson, J. C. Gordon, D. J. Vogt and A. Fanzeres, "Forest Certification: Roots, Issues, Challenges, and Benefits,” CRC Press, Boca Raton, 2000.

[52] M. Williams, "Deforesting the Earth: From Prehistory to Global Crisis, an Abridgement,” Kluwer Academic Publishers, Dordrecht, 2006. doi:10.7208/chicago/9780226899053.001.0001

[53] P. Perera and R. P. Vlosky, "A History of Forest Certification,” Forest Products Development Center Working Paper No. 71, Louisiana State University, Baton Rouge, 2006. 
[54] D. Klooster, "Environmental Certification of Forests: The Evolution of Environmental Governance in a Commodity Network,” Journal of Rural Studies, Vol. 21, No. 4, 2005, pp. 403-417. doi:10.1016/j.jrurstud.2005.08.005

[55] K. von Gadow, T. Pukkala and M. Tomé, "Sustainable Forest Management," Kluwer Academic Publishers, Dordrecht, 2002.

[56] P. B. Durst, P. J. McKenzie, C. L. Brown and S. Appanah, "Challenges Facing Certification and Eco-Labeling of Forest Products in Developing Countries," International Forestry Review, Vol. 8, No. 2, 2006, pp. 193-200. doi:10.1505/ifor.8.2.193

[57] B. Holvoet and B. Muys, "Sustainable Forest Management Worldwide: A Comparative Assessment of Standards," International Forestry Review, Vol. 6, No. 2, 2004, pp. 99-122. doi:10.1505/ifor.6.2.99.38388

[58] G. T. McDonald and M. B. Lane, "Converging Global Indicators for Sustainable Forest Management," Forest Policy and Economics, Vol. 6, No. 1, 2004, pp. 63-70. doi:10.1016/S1389-9341(02)00101-6

[59] C. Fischer, F. Aguilar, P. Jawahar and R. Sedjo, "Forest Certification: Toward Common Standards," Resources for the Future, Washington DC, 2005.

[60] World Commission on Forests and Sustainable Development, “Our Forests, Our Future,” Cambridge University
Press, Cambridge, 1999.

[61] A. E. Patterson, "Technique of Forest Management Plan Preparation,” Self-published, Athens, 1960.

[62] S. Loveland, "Good Forestry Starts with a Good Plan," Forest Landowner, Vol. 62, No. 3, 2003, pp. 14-15.

[63] M. Webb, "The Forest Management Plan: Key to the Future,” Forest Landowner, Vol. 60, No. 4, 2001, pp. 23-25.

[64] T. J. Straka, "Forest Management Plans for Small Holdings,” Forest Landowner, Vol. 56, No. 5, 1997, pp. 34-35, 38-39.

[65] B. Hatcher, “The Management Plan,” In: M. J. Wallace and A. Londo, Eds., Managing the Family Forest in Mississippi, Mississippi State University, Department of Forestry, Mississippi State, 2008, pp. 8-15.

[66] R. M. Shaffer, "A Guide to Harvest Planning," The Consultant, Vol. 37, No. 3, 1992, pp. 12-15.

[67] E. C. Frazer III, "Effective Forest Management," Forest Farmer, Vol. 42, No. 5, 1983, pp. 18-21.

[68] L. K. Larson, "Managing Small Forest Holdings," Forest Farmer, Vol. 33, No. 2, 1973, pp. 9, 28.

[69] E. C. Frazer III and P. Hodgkins, “Timber Management Plans for Modest-Sized Landowners,” Forest Farmer, Vol. 36, No. 5, 1977, pp. 11-13. 